\title{
Studying Mustahik Requirements Based on Had Kifayah Benchmark: A Case from East Nusa Tenggara (NTT)
}

\author{
Kamilah Kinanti \\ The National Library of Indonesia
}

\begin{abstract}
As an effort to optimize the transparent and measurable zakat management, BAZNAS Center of Strategic Studies has been developing several instruments, including the Had Kifayah measure. The measurement is the standard limit of basic needs of a Muslim, which is helpful to consider the requirements of zakat recipients. By employing Had Kifayah, this paper performs a case study from Nusa Tenggara Timur (NTT) Province in 2018 and finds that NTT had the highest cost of living of IDR3,363,105.00 per family (monthly). This paper covers the preliminary study verifying the categorization pyramid as in Had Kifayah standard to investigate the changes of a mustahik income and expenditure before and after the productive zakat program of BAZNAS. The results show that the program conducted by BAZNAS-NTT from 2016 to 2017 is found to be in the fourth priority on the Had Kifayah pyramid.
\end{abstract}

Keyword: Had Kifayah, priority pyramid of Had Kifayah, Mustahik of Productive Zakat Program, Nusa Tenggara Timur (NTT)

\section{INTRODUCTION}

In exploring the issue of poverty and welfare, the measurement instrument is necessary. The device is useful for measuring and considering recommendations that are appropriate to the items being explored. In Indonesia, there are many concepts developed by government agencies to determine the level of welfare or poverty in society. One example that is often used to sufficiently capture the Muslim living needs standard is Had Kifayah yardstick as developed by BAZNAS Center of Strategic Studies (Puskas BAZNAS). Had Kifayah can best understand as the limit of basic standards needs of a person or family with the adequacy of existing dependents as an effort to determine the eligibility of zakat recipients of poor people according to local socio- economic conditions (Puskas BAZNAS, 2018). The existence of Had Kifayah is beneficial to describe the subject matters. The amount of Had Kifayah varies in each province since the price of goods and services are different.

The result of Had Kifayah study conducted in 2018 found that NTT was the highest Had Kifayah number with IDR3,363,105 (USD232,11) per family or IDR862,335 (USD59,51) per capita per month. Moreover, the 2017 Zakat Impact Assessment conducted by Puskas BAZNAS, also found that NTT performed the highest score of 0.85 (very good), indicating that the distribution of zakat by the respective BAZNAS has been contributing to a positive impact towards Mustahik (zakat recipient) (Puskas BAZNAS, 2017).

As elaborated above, the proper implementation of the productive zakat 
distribution program by the BAZNAS of NTT in 2017, with regard to reaching the right Mustahik based on $\mathrm{Had}$ Kifayah standard demands further a scientific discussion. For this purpose, we address the following question: has the productive zakat program of BAZNAS NTT targeted the ideal Mustahik based on Had Kifayah measure?

\section{LITERATURE REVIEW}

\section{The Concept of Had Kifayah}

Had Kifayah is an Arabic word, which means enough, sufficient for something important or adequate for life. Thus one does not need the help of others (Puskas BAZNAS, 2018). Aside from the tendency to make a standard of living against what has been issued by the national government, the Had Kifayah establishment was driven to best capture the living standards of Muslim.

In 2017, the figure of Indonesia's poverty rate (GK) was IDR379,756 (USD26,21) per capita. In 2018, the Indonesia GK figure rose to IDR404,362 (USD27,91) per capita. In 2017, the amount of GK's NTT Province was IDR367,953 (USD25,39) per capita, in 2018, it was rose to IDR379,817 (USD26,21) (BPS, 2019). Subsequently, the domestic standard living measure (KHL) in Indonesia in 2015 was IDR1,813,396 (USD125,15), and that of NTT's KHL was IDR1,652,137 (USD114,02) (BPS, 2015). While, Had Kifayah number of Indonesia in 2018 is IDR772,088 (USD53,29) per capita or IDR3,011,142 (USD207,82) per household (Puskas BAZNAS, 2018).

Elaborated the three standards above, best help us to understand that GK defines the lowest amount from KHL. KHL represents a quite high number as it sets a decent living need.
Had Kifayah itself places medium define between GK and KHL with the more acceptable amount.

The significant differences also can be seen in the dimensional component of this standard. Puskas BAZNAS employed 7 dimensions as basic needs, which are food, clothing, residency, worship, education, health, and transportation. The consideration is based on the kind of kifayah which can be in the form of basic needs (Had Kafaf) that are suitable for normal life such as education, health and transportation, and other urgent needs (Had Fawqa Kafaf).

In terms of its constituent dimensions, Had Kifayah is quite different from the two other concepts of poverty or welfare measurement issued by the Indonesian government. In the context of zakat, there are some fundamental aspects which are also not covered by GK or KHL. For example; worship needs are not measured within those two standards. In Islam, worship is obligatory. Hence, it is rational to say that Had Kifayah benchmark is more ideal for measuring the extent to which the zakat funds distributed has impacted the Mustahik.

Had Kifayah is also useful both in looking at the position of a Muslim from the standpoint of either one being a Mustahik or Muzaki. And the substantive category of prosperity. These indicators have yet to be accommodated by the pre-existing standard of living. In Had Kifayah yardstick of Puskas BAZNAS, there is a pyramid as an indicator which best suggests appropriate programs for Mustahik. Figure 1 depicts the Had Kifayah priority pyramid. The grey area indicates the proper plan of consumptive zakat distribution. This is because the income in the range still struggles to fulfill the basic needs. 
Meanwhile, those whose income is in the range between Had Kifayah and Nishab Zakat (black area) are considered to be able to fulfill their basic needs, but economically they are still vulnerable to the lower level. For this, the right program is productive zakat. The formula of Had Kifayah as from Puskas BAZNAS is as follows:

$$
H K=\sum_{i=1}^{7} X i
$$

Note:
HK: Had Kifayah
$X_{1}$ : Had Kifayah of Food
$X_{2}$ : Had Kifayah of Clothing
$X_{3}$ : Had Kifayah of Residency
$X_{4}$ : Had Kifayah of Worship
$X_{5}$ : Had Kifayah of Education
$X_{6}$ : Had Kifayah of Health
$X_{7}$ : Had Kifayah of Transportation

Figure 1. Had Kifayah Priority Pyramid

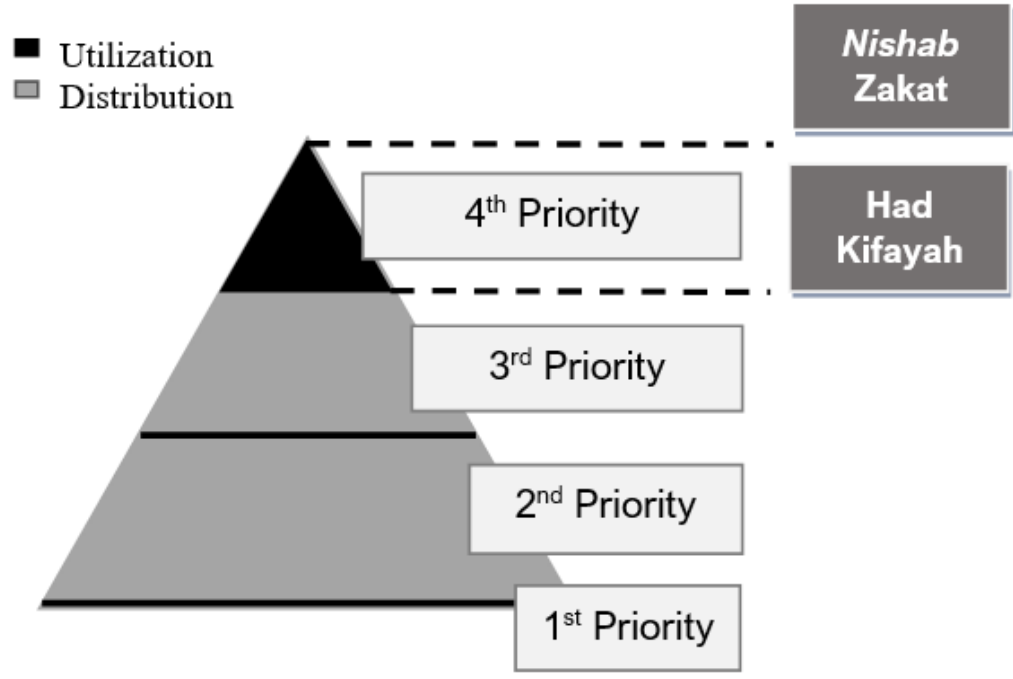

$$
\begin{aligned}
& 1^{\text {st }} \text { Priority : < IDR 1,003,714 (USD69,27) } \\
& 2^{\text {nd }} \text { Priority : IDR 1,003,714 - IDR2,007,428 (USD69,27-USD138,54) } \\
& 3^{\text {rd }} \text { Priority : IDR2,007,428 - IDR3,011,142 (USD138,54-USD207,82) } \\
& 4^{\text {th }} \text { Priority : IDR3,011,142 - IDR4,159,999 (USD207,82 -USD287,11) }
\end{aligned}
$$

Source: Puskas BAZNAS (2018)

\section{The Economy of Nusa Tenggara Timur}

Based on the Central Bureau of Statistics of NTT, the total population in 2016 was 5,203,514 people. The entire workforce was 2,353,648 people with a percentage of 97 percent working and 3 percent unemployed (Sakernas BPS, 2016). The largest employment sector in NTT is by agriculture, forestry, plantation, and fisheries with the number of 1,214,060 workers.

In education, the total population with a high school education level is 52.87 percent, and elementary school education is 95.24 percent. While the residents who do not have a diploma is 33.30 percent, with illiteracy rates of 7.40 percent. Until 2016, the number of schools in NTT was 7,630 units including 5,171 Elementary 
School, 1,667 Junior High School, and 792 Senior High School.

Despite a decline from the previous year, the poverty rate in NTT until 2016 is quite high at $22.19 \%$. BAZNAS of NTT runs the program to reduce poverty in NTT through the distribution of consumptive and productive zakat programs.

\section{Zakat Impact Measurement in 2017}

For productive zakat programs, BAZNAS has set 5 main dimensions, which are economics, education, health, social, and da'wah. BAZNAS in all provinces adopted these dimensions with a different program according to the needs of each region. Table 1 explains the example of productive zakat program of BAZNAS NTT.

BAZNAS developed Zakat Impact Measurement to analyze the performance of Zakat program. This study uses an index called the Puskas Welfare Index (IKP), which is used to measure the impact of zakat utilization. IKP is an index consists of 3 variables, namely the CIBEST Welfare Index, which measures material and spiritual welfare, the HDI Modification Index, which measures the impact of zakat on the education and health sectors, and the Independence Index, which measures the sustainability of post-program Mustahik (Puskas BAZNAS, 2017). The range of IKP score is as of table 2.

Zakat Impact Assessment has been started since 2016. In the recent report of 2017, which such an assessment was carried out in 28 provinces, there were five provinces which scored 0.85 (very good), included NTT. This result means that the distribution of zakat by the respective BAZNAS have a positive impact on Mustahik.

Table 1. Productive distribution planning program of BAZNAS NTT Province year 2019

\begin{tabular}{|c|c|c|c|}
\hline No & Program & Details & $\begin{array}{c}\text { Percentage } \\
(\%)\end{array}$ \\
\hline 1 & Economic & $\begin{array}{l}\text { Zakat Community Development (ZCD) } \\
\text { Program ZCD } 1 \\
\text { Program ZCD } 2 \\
\text { Economic Empowerment Program } \\
\text { Business capital program } \\
\text { Business training program } \\
\text { Mustahik cooperative }\end{array}$ & $44.2 \%$ \\
\hline 2 & Education & $\begin{array}{l}\text { Educational Scholarship Program } \\
\text { Primary school scholarship } \\
\text { Secondary school scholarship } \\
\text { High school scholarship } \\
\text { Collage school scholarship } \\
\text { Undergraduate scholarship } \\
\text { Education Service Program } \\
\text { Education loan aid } \\
\text { Tuition support } \\
\text { Mustahik learning guidance } \\
\text { Character development }\end{array}$ & $11.9 \%$ \\
\hline 3 & Health & $\begin{array}{l}\text { Health Service Program } \\
\text { Debt relief treatment }\end{array}$ & $3.3 \%$ \\
\hline
\end{tabular}




\begin{tabular}{|c|c|c|c|}
\hline No & Program & Details & $\begin{array}{c}\text { Percentage } \\
(\%)\end{array}$ \\
\hline & & $\begin{array}{l}\text { Medical expenses assistance } \\
\text { Ambulance operations } \\
\text { Ambulance procurement } \\
\text { Mustahik integrated health post } \\
\text { BAZNAS Healthy House } \\
\text { BAZNAS healthy home construction } \\
\text { BAZNAS healthy home operations }\end{array}$ & \\
\hline 4 & $\begin{array}{l}\text { Da'wah- } \\
\text { Advocacy }\end{array}$ & $\begin{array}{l}\text { Da'wah Service Program } \\
\text { Zakat fitrah package (Ied Fitr) } \\
\text { Ramadan iftar package } \\
\text { Sacrifice (qurban) package } \\
\text { Clean and healthy living behavior support } \\
\text { Compensation for converts (mualaf) } \\
\text { Da'i family benefits from disadvantaged, } \\
\text { outermost, and remote areas } \\
\text { Da'i prosperous compensation } \\
\text { Islamic development class } \\
\text { Da'i development class } \\
\text { Marriage fees support } \\
\text { Circumcision fee assistance } \\
\text { Mustahik advocacy } \\
\text { Islamic community organizations assistance }\end{array}$ & $31.5 \%$ \\
\hline 5 & Humanity & $\begin{array}{l}\text { Humanitarian Services Program } \\
\text { Fakir compensation } \\
\text { House lease loans assistance } \\
\text { Home renovation assistance } \\
\text { Ibnu Sabil support } \\
\text { Compensation for death } \\
\text { Disaster assistance }\end{array}$ & $9.1 \%$ \\
\hline
\end{tabular}

Source: BAZNAS (2019)

Table 2. Puskas Welfare Index (IKP) Range of Scores

\begin{tabular}{|c|c|}
\hline Range of Scores & Categorization \\
\hline $\mathbf{0 , 0 0 - 0 , 2 0}$ & Not good \\
\hline $\mathbf{0 , 2 1 - 0 , 4 0}$ & Less good \\
$\mathbf{0 , 4 1 - 0 , 6 0}$ & Quite good \\
\hline $\mathbf{0 , 6 1 - 0 , 8 0}$ & Good \\
\hline $\mathbf{0 , 8 1 - 1 , 0 0}$ & Very good \\
\hline
\end{tabular}

Source: Puskas BAZNAS (2017).

\section{RESEARCH METHODS}

We engaged qualitative method of descriptive analysis, which Creswell (2018) explained it to exploring and understanding the meaning of individuals or groups derived from human social problems. The investigation was built inductively from a particular theme to the public. The descriptive analysis used to describe a phenomenon existence using regular review, prioritizing objectivity, carried out carefully, no treatment given or 
controlled, and no test h (Furchan, 2004).

The data was from the Zakat Impact Measurement on the amount of Mustahik income per household in 2017 in NTT as well as the data from the Had Kifayah study regarding the case in NTT. The number of the respondent during Zakat Impact Assessment of 2017 in NTT was 100 respondents, which were from Kupang Regency and Kupang City. We used Mustahik data profile from Zakat Impact Measurement questionnaire, then verifying the average income of the Mustahik zakat productive program with Had Kifayah measurement.

\section{RESULTS}

With the Had Kifayah standard, we verified the zakat utilization program by BAZNAS-NTT from 2016 to 2017. In 2017, NTT obtained IKP of 0.85 (very good). Score 1 on the Cibest Welfare Index, 0.75 on the HDI Modification Index, and 0.75 on the Independence Index. This means that the distribution of zakat carried out by BAZNAS in NTT provided positive results for the assisted Mustahik. Table 3 shows the results.

The average income of productive program Mustahik before the program was IDR3,299,956

(USD227,75) /month/household. The majority jobs are small traders/stalls at home $(41.86 \%)$, traders $(17.25 \%)$, farmers (17.25\%), employees (17.25\%), and laborers $(17.25 \%)$. The average amount of productive assistance received per household was IDR1,025,000 (USD70,74). Based on 100 respondents, 14 respondents received productive as well as consumptive assistance with an average consumptive assistance of IDR1,098,929 (USD75,84) per household. Meanwhile, the average income of respondents after receiving zakat program is IDR5,197,766 (USD358,73) or increased by IDR1,908,810 (USD131,74). In terms of expenditure, the average expenditure per household of the respondents is as table 4.

The most significant expenditure is food consumption, which is IDR893,500 (USD61,67) or $30 \%$ of the total spending. From many expenditure points as of table 4, there are some expenditure variables which are not classified as emergency needs, namely communication, cigarettes, entertainment, cosmetics, celebration donations, and debt/installments/credit.

Table 3. Zakat Impact Assessment year 2017 in Nusa Tenggara Timur Province

\begin{tabular}{|c|c|c|c|}
\hline No & Description & $\begin{array}{l}\text { Number of } \\
\text { Household } \\
\text { Recipients }\end{array}$ & Amount \\
\hline 1 & Average income before assisted & 100 & IDR3,288,956 (USD226,99) \\
\hline 2 & Average consumptive assistance & 14 & IDR1,098,929 (USD75,84) \\
\hline 3 & Average productive assistance & 100 & IDR1,025,000 (USD70,74) \\
\hline 4 & Average income after assisted & 100 & IDR5,197,766 (USD358,73) \\
\hline
\end{tabular}

Source: BAZNAS (2017). 
Table 4. Expenditure composition of Zakat Impact Assessment

\begin{tabular}{|c|c|c|c|}
\hline No & & escription & Amount \\
\hline 1 & \multicolumn{2}{|c|}{ Residential rental } & IDR258,000 (USD17,81) \\
\hline 2 & \multicolumn{2}{|c|}{ Electricity \& water costs } & IDR260,100 (USD17,95) \\
\hline 3 & \multicolumn{2}{|c|}{ Food costs } & IDR893,500 (USD61,67) \\
\hline \multirow[t]{2}{*}{4} & \multirow{2}{*}{ School fees } & Monthly fees & IDR512,500 (USD35,37) \\
\hline & & Pocket money & IDR236,020 (USD16,29) \\
\hline 5 & \multicolumn{2}{|c|}{ Transportation costs } & IDR185,200 (USD12,78) \\
\hline 6 & \multicolumn{2}{|c|}{ Communication costs } & IDR171,570 (USD11,84) \\
\hline \multirow[t]{2}{*}{7} & \multirow{2}{*}{ Health } & Drugs & IDR39665 (USD2,74) \\
\hline & & Medical consultation & IDR4,000 (USD0,28) \\
\hline 8 & \multicolumn{2}{|l|}{ Clothes } & IDR43,500 (USD3,00) \\
\hline 9 & \multicolumn{2}{|l|}{ Cosmetics } & IDR35,000 (USD2,42) \\
\hline 10 & \multicolumn{2}{|l|}{ Cigarettes } & IDR51,250 (USD3,54) \\
\hline 11 & \multicolumn{2}{|c|}{ Celebration donations } & IDR59,100 (USD4,08) \\
\hline 12 & \multicolumn{2}{|c|}{ Entertainment; Night market etc. } & IDR12000 (USD0,83) \\
\hline 13 & \multicolumn{2}{|c|}{ Debt / installments / credit } & IDR169,510 (USD11,70) \\
\hline \multicolumn{3}{|c|}{ Total Monthly Household Expenditures } & IDR2,930,915 (USD202,28) \\
\hline
\end{tabular}

Source: BAZNAS (2017).

Accuracy of the Program based on the Priority Scale of Had Kifayah

The study of Had Kifayah 2018 disclosed that the cost of living in NTT was in the first place, which means that the cost of living in this province is the most expensive among the 33 other provinces in Indonesia. The size of Had Kifayah in the food dimension in NTT was IDR2,124,287 (USD146,61). For clothing was IDR56,431 (USD 3,89) for adult male, IDR42,563 (USD2,94) for adult female, and IDR28,960 (USD2,00) for children. In the dimensions of residence and household facilities, the constituent components consist of residential, water, electricity, and gas, the total number of $\mathrm{Had}$ Kifayah was IDR637,076 (USD43,97).

In the dimension of worship, the Had Kifayah figure wasIDR18,875 (USD1,30) for an adult male, IDR15,000 (USD1,04) for an adult female, and IDR16,938 (USD1,17) for children. The Had Kifayah on the education dimension was IDR104,167 (USD7,19) for Elementary School, IDR145,833 (USD10,06) for Junior High School, IDR200,000 (USD13,80) for Senior High School, and IDR183,333 (USD12,65) for Islamic Senior High School. Health dimension of Had Kifayah was IDR19,225 (USD1,33) for health insurance, and the assistance was IDR300,000 (USD20,70) for severe conditional disability. Transportation dimension of $\mathrm{Had}$ Kifayah scale were IDR41,002 (USD2,83) for gasoline, IDR11,834 (USD0,82) for land transportation, and IDR478 (USD0,033) for sea transportation.

By assuming the average number of Indonesian family members that is four people (BPS, 2017), which includes one father, one mother, one junior high school age child, and one 
elementary school age child, then the NTT Had Kifayah numbers are as follows:

$$
\begin{aligned}
H K= & X_{1}+X_{2}+X_{3}+X_{4}+X_{5} \\
& +X_{6}+X_{7} \\
= & 2124287+156914+ \\
& 637076+67751+ \\
& 250000+19225+ \\
& 53314 \\
= & 3308567(\text { IDR })
\end{aligned}
$$

Further, referring to the 2017 Impact Assessment data, a comparison could be made between the amount of Had Kifayah figures and the Mustahik income of the productive program of the NTT BAZNAS as follows:

Table 5. Mustahik income of the productive program of the NTT Province BAZNAS

\begin{tabular}{|l|l|}
\multicolumn{1}{|c|}{ Explanation } & \multicolumn{1}{c|}{ Quantity } \\
\hline $\begin{array}{l}\text { Number of Respondent } \\
\text { (household unit) }\end{array}$ & 100 \\
\hline $\begin{array}{l}\text { The average number } \\
\text { of mustahik family } \\
\text { members }\end{array}$ & 4 \\
\hline $\begin{array}{l}\text { Average income before } \\
\text { receiving zakat assistance }\end{array}$ & $\begin{array}{l}\text { IDR3,288,956 } \\
\text { (USD226,99) }\end{array}$ \\
\hline $\begin{array}{l}\text { Average income after } \\
\text { receiving zakat assistance }\end{array}$ & $\begin{array}{l}\text { IDR5,197,766 } \\
\text { (USD358,73) }\end{array}$ \\
\hline $\begin{array}{l}\text { Standard Had Kifayah per } \\
\text { household in NTT } \\
\text { Province }\end{array}$ & $\begin{array}{l}\text { IDR3,363,105 } \\
\text { (USD232,11) }\end{array}$ \\
\hline
\end{tabular}

Source: Prepared by authors.

The average income of BAZNAS of NTT Mustahik before the implementation of the productive zakat program was IDR3,288,956 (USD226,99) per month, which was below the standard of Had Kifayah of NTT. The difference between the respondents' income and the Had Kifayah standard was IDR74,149 (USD5,12). Following productive zakat assistance, the average income of the respondents was IDR5,197,766

(USD358,73), increased by IDR1,908,810 (USD131,74).

From the data above, it can be seen that the average income of respondents before the program was below the standard of NTT Had Kifayah; that is IDR3, 363,105 (USD232,11), with a difference of IDR74,149 (USD5,12). It glance means they include in third priority, which is distribution assistance, or zakat program for consumption. However, based on the numerical unit of priority pyramid, the productive program of BAZNAS in NTT was included in the fourth priority with an income range of IDR3,011,142 - IDR4,159,999 (USD207,82 USD287,11). So that, it also can fit to become a recipient of utilization assistance by using this numerical justification of Had Kifayah yardstick.

In all, the accuracy of the program of BAZNAS-NTT is reasonable. This is due to the indication of the high score of the Puskas Welfare Index was 0.85 , and the increase of respondents' income was IDR1,908,810 (USD131,74).

\section{CONCLUSION}

After comparing several profile data of Mustahik above, it can be concluded the categorization of the Had Kifayah priority pyramid is generally quite good in verifying the economic condition of the prospective recipients of zakat assistance. The average income of mustahik was in the third priority; Mustahik should be assisted with the consumptive zakat program. However, by looking at the numerical evidence within the Had Kifayah measurement, the Mustahik of zakat productive program of the BAZNAS NTT was in the fourth priority; which Mustahik should be covered by productive zakat program. 
By the slight difference between Had Kifayah in NTT Province and the categorization of Had Kifayah priority pyramid, we recommend further study of Had Kifayah priority pyramid component to elevate the accuracy of this standard in the future.

Aside from the categorization, the selection of NTT BAZNAS beneficiaries on productive program scored well; this can be concluded since the amount of income of Mustahik is nearly match with the productive program priority on Had Kifayah priority pyramid. The accuracy of the program implementation is reflective within in the results of the 2017 Zakat Impact Assessment which obtained the Puskas Welfare Index score of 0.85 very good, and the increase of respondents' income is IDR1,908,810 (USD131,74).

\section{REFERENCE}

A Furchan. (2004). Pengantar Penelitian dalam Pendidikan. Yogyakarta: Pustaka Pelajar Offset.

Creswell, J. W., \& Creswell, J. D., (2017). Research Design: Qualitative, Quantitative, and Mixed Methods Approaches. USA: Sage.

Indonesia, Republic. (2016). Peraturan Menteri Ketenagakerjaan Republik Indonesia Nomor 21 Tahun 2016 tentang Kebutuhan Hidup Layak. Jakarta: Kementerian Ketenagakerjaan.

Indonesia, Republic-Pusat Kajian Strategis BAZNAS. (2017). Dampak Zakat Terhadap Kesejahteraan Mustahik di Indonesia: Evaluasi Program Zakat Produktif BAZNAS. . Jakarta: Puskas BAZNAS.

Indonesia, Republic-Pusat Kajian Strategis BAZNAS. (2019).
Confidential document: $L K M$ RKAT Nusa Tenggara Timur. Jakarta: Bagian rencana dan Pengembangan BAZNAS.

Indonesia, Republic-Badan Pusat Statistik. (2017). Provinsi Nusa Tenggara Timur Dalam Angka. Jakarta: BPS.

Indonesia, Republic-Badan Pusat Statistik. (2017). Banyaknya Rumah Tangga menurut Provinsi, 2000-2015. Jakarta: BPS. Source: https://www.bps.go.id/dynamictab le/2015/09/07/851/banyaknyarumah-tangga-menurut-provinsi2000-2015.html. Accesed on 29 April 2019, 13.30 pm.

Indonesia, Republic-Badan Pusat Statistik. (2015). Kebutuhan Hidup Minimum/Layak (Khm/Khl) Selama Sebulan Menurut Provinsi. Source: https://www.bps.go.id/linkTableD inamis/iew/id/1212. Accesed on 29 April 2019, $12.41 \mathrm{pm}$.

Indonesia, Republic-Badan Pusat Statistik. (2019). Garis Kemiskinan Menurut Provinsi. Source:

https://www.bps.go.id/dynamictab le/2016/01/18/1120/garis-

kemiskinan-menurut-provinsi2013---2018.html. Accesed on 29 April 2019, 11.30 pm.

Indonesia, Republic-Pusat Kajian Strategis BAZNAS. (2018). Kajian Had Kifayah. Dalam P. BAZNAS, Kajian Had Kifayah. Jakarta: Puskas BAZNAS.

Raco, J. (2010). Metode Penelitian Kualitatif: Jenis, Karakteristik, dan Keunggulannya. Jakarta: Grasindo.

Rasyad, R. (2003). Metode Statistik Deskriptif Untuk Umum. Jakarta: Grasindo. 
